Research article

\title{
Valorization of hazelnut shell waste in hot compressed water
}

\author{
Gokalp Gozaydin, Asli Yuksel * \\ Izmir Institute of Technology, Chemical Engineering Department, Urla, Izmir 35430, Turkey
}

\section{A R T I C L E I N F O}

\section{Article history:}

Received 18 October 2016

Received in revised form 23 May 2017

Accepted 29 May 2017

Available online 3 June 2017

\section{Keywords:}

Hazelnut shell

Sub-critical water

Hydrothermal conversion

Levulinic acid

Furfural

Acetic acid

\begin{abstract}
A B S T R A C T
Hydrothermal conversion of waste hazelnut shell in hot compressed water, green and environmentally friendly medium, was investigated under different operating conditions to clarify the effects of reaction temperature, reaction time, acid concentration and acid kind $\left(\mathrm{H}_{2} \mathrm{SO}_{4}\right.$ and $\left.\mathrm{H}_{3} \mathrm{PO}_{4}\right)$ on the production of value-added chemicals with high temperature/high pressure autoclave. In literature, to our best knowledge, there is no study about the production of levulinic acid, as a high value chemical, from waste hazelnut shell in hot-compressed water without using any mineral and heterogeneous catalyst. Hydrothermal reactions were conducted at $150-280{ }^{\circ} \mathrm{C}$ for reaction times of 15 to 120 min with various $\mathrm{H}_{2} \mathrm{SO}_{4}$ and $\mathrm{H}_{3} \mathrm{PO}_{4}$ concentrations varying from 0 to $125 \mathrm{mM}$. The detailed liquid product species were identified with High Performance Liquid Chromatography (HPLC) and gaseous products were analyzed by Gas Chromatography with a Thermal Conductivity Detector (GC-TCD). The main identified liquid compounds were levulinic acid, acetic acid and furfural while carbon dioxide and carbon monoxide were the major gaseous products. Increasing the reaction temperature $\left(280{ }^{\circ} \mathrm{C}\right)$ and reaction time (120 $\mathrm{min}$ ) resulted in a significant increment on the conversion (65.40\%) as well as levulinic acid yield (13.05\%). The production of levulinic acid was enhanced with $\mathrm{H}_{2} \mathrm{SO}_{4}$ addition; whereas treatments with $\mathrm{H}_{3} \mathrm{PO}_{4}$ improved the furfural production.
\end{abstract}

(C) 2017 Elsevier B.V. All rights reserved.

\section{Introduction}

Population growth, scarce of petroleum reserves and environmental concerns improved the interest of investigation of alternative and renewable resources [1,2]. The utilization of biomass seems the most important alternative to fossil fuels in the production of value-added chemicals due to being carbon neutral source, not having and contribution to net $\mathrm{CO}_{2}$ concentration in the atmosphere and reduce the waste problem with effective conversion [3].

A wide variety of bio-based chemicals (i.e. levulinic acid, acetic acid and furfural) can be produced from the degradation of different biomass types. Among them levulinic acid is a versatile chemical that can be used to produce a great number of derived products such as pharmaceutical and flavouring agents, resins, herbicides, plasticisers, anti-freeze agents and biofuel additives. Several technologies such as mineral acids, solid catalyst, ionic liquids and sub- or supercritical fluids have been performed during the production of levulinic acid from different raw materials [4]. To our best knowledge, this study is the first one that investigates levulinic acid production from waste hazelnut shell in hot-compressed water, which is environmentally friendly, non-toxic, cheap, non-flammable and abundant.

\footnotetext{
* Corresponding author.

E-mail address: asliyuksel@iyte.edu.tr (A. Yuksel).
}

Near critical point $\left(374{ }^{\circ} \mathrm{C}\right.$ and $22.1 \mathrm{MPa}$ ), water exists in liquid state under enough pressure [5] which possesses unique solvation and physicochemical properties. Temperature increment results in reduce in water polarity (non-polar) [6] and the solvation power of organic compounds enhances [7]. The ion product $\left(K_{w}\right)$ of water increases with temperature and reaches to $10^{-11}$ that is approximately three orders of magnitude higher than the ion product of ambient water and the dielectric constant $(\varepsilon)$ of ambient water is reduced from 80 to 10 at around $374{ }^{\circ} \mathrm{C}[8,9]$. Furthermore, low dielectric constant boosts ionic reaction and the high concentration of $\mathrm{H}_{3} \mathrm{O}^{+}$and $\mathrm{OH}^{-}$ions enables to water acts as an acid or base catalyst in subcritical water region [8].

Several researchers reported natural biomass conversion in subcritical water. Chan et al. [10] conducted series of experiments for the comparison of chemical species from subcritical and supercritical hydrothermal liquefaction of various biomasses: empty fruit bunch, palm mesocarp fiber and palm kernel shell. They stated that content of biomass had remarkable influence on the distribution of the products. Higher amounts of phenolic compounds were produced from palm mesocarp fiber and palm kernel shell while alcohol and ester were only formed from palm kernel shell. Kruse and Gawlik [11] described possible reaction pathways from the degradation of phytomass, which was mainly composed of cooked carrots and potatoes. The degradation of HMF occurred with two different pathways: the formation of 1,2,4benzenetriol and the formation of levulinic acid (via acid catalyst). They also identified key components including HMF, levulinic acid, 
acetic acid and furfural. In another study, the hydrothermal degradation of switchgrass at $250-350^{\circ} \mathrm{C}$ and $20 \mathrm{MPa}$ with $1-300$ s residence time to obtain the maximum conversion and desired product yield (5-HMF and furfural) were examined and rapid switchgrass conversion (90 wt\%) was achieved which is $<60 \mathrm{~s}$ [12]. Moreover, many researches have focused on the influence of different acid addition on the conversion of biomass and valuable chemical production. Takeuchi et al. [13] noticed that the production of valuable chemical species from carbohydrate biomass (glucose) vary with respect to acid type. The production of 5-HMF increased in the presence of $\mathrm{H}_{3} \mathrm{PO}_{4}$ while $\mathrm{H}_{2} \mathrm{SO}_{4}$ enhanced the levulinic acid production. Asghari and Yoshida [14] evaluated that the effect of dilute phosphate buffer at $\mathrm{pH} 2$ on the conversion of Japanese red pine wood under subcritical water. When compared to uncatalyzed conditions, Japanese red pine wood decomposed into higher amount of sugars within shorter time and the yield of HMF and furfural were nearly doubled with a further treatment. Tymchyshyn and $\mathrm{Xu}$ [15] reported that the degradation of sawdust and cornstalks into phenolic compounds at $250-350{ }^{\circ} \mathrm{C}$ and $2 \mathrm{MPa} \mathrm{H}_{2}$ with the addition of $\mathrm{Ba}(\mathrm{OH})_{2}$ and $\mathrm{RbCO}_{3}$ catalysts. Addition of catalysts greatly enhanced the bio-oil yield whose composition mainly consisted of 2-methoxy-phenol, 4ethyl-2-methoxy-phenol and 2,6-dimethoxy-phenol.

Among different biomasses in literature, it was noticed that limited number of studies focused on the hydrothermal conversion of nut wastes (walnut, peanut etc.) in subcritical water. Zhu et al. [16] studied hydrolysis kinetics of waste peanut shell in subcritical water and possible reaction mechanisms. The yield of reducing sugars increased to 40.5\%. Liu et al. [17] examined the catalytic degradation of walnut shells under hot compressed water $\left(200-300{ }^{\circ} \mathrm{C}\right.$ and $\left.1.5-8.6 \mathrm{MPa}\right)$ with the addition of $\mathrm{KOH}$ and $\mathrm{HCl}$. They concluded that the methoxy phenolic compounds, cyclopentene derivatives $\mathrm{C} 12-\mathrm{C} 18$ fatty acids were detected in the $\mathrm{KOH}(0.5 \mathrm{M})$ catalyzed treatment while the presence of $\mathrm{HCl}$ improved the levulinic acid yield up to $12 \%$. The majority of the studies about waste nut shell degradation under hydrothermal conditions focused on the product distribution, reaction mechanism and kinetics. In order to have idea about bioactivity results (total phenolic content, antioxidant activity, etc.) of the products obtained from waste nut shells, extraction studies in the literature would be reviewed. Shahidi et al. [18] evaluated that the extracts of hazelnut byproducts (skin, hard shell, green leafy cover and tree leaf) had higher amount of antioxidants and phenolic content than hazelnut kernel extract after ethanol extraction. Contini et al. [19] compared the total phenolic content of hazelnut shell, whole and chopped roasted hazelnut skins with using $80 \%(\mathrm{v} / \mathrm{v})$ acetone, methanol and ethanol. The total phenolic content of hazelnut shell from acetone extract ( $72.2 \mathrm{mg}$ of gallic acid equivalent (GAE)/g extract) was higher than those of ethanol (59.6 mg of GAE/g extract) and methanol extracts ( $56.6 \mathrm{mg}$ of GAE/g extract). The highest phenolic content was obtained from whole roasted hazelnut skin for three solvents.

Hazelnut is an agricultural crop that is cultivated in substantial amount in Turkey. Turkey leads in hazelnut production with supplying $75 \%$ of the global hazelnut production in the World $(650,000$ tons/year). Large amount of waste hazelnut shells are produced during hazelnut processing and most of them are used for heating [20]. Therefore, the utilization of waste hazelnut shell in the production of value-added chemicals can contribute both in value gaining and being natural alternative resource.

To our best knowledge, conversion of waste hazelnut shell to valuable chemicals such as levulinic acid in hot-compressed water was done for the first time in literature. The main objective of this study is to investigate the potential role of waste hazelnut shell as a biomass feedstock for the production of mainly levulinic acid under hydrothermal conditions. The effect of reaction temperature $\left(150-280^{\circ} \mathrm{C}\right)$, reaction time (15-120 min), acid concentration (0-125 mM), and acid type $\left(\mathrm{H}_{2} \mathrm{SO}_{4}\right.$ and $\left.\mathrm{H}_{3} \mathrm{PO}_{4}\right)$ on the conversion of hazelnut shell and the selectivities of valuable chemicals in the liquid product solution were investigated. The total phenolic content and the antioxidant activity of the product solution were also analyzed.

\section{Materials and methods}

\subsection{Materials}

Hazelnut shell was used as biomass feedstock from Ordu, Turkey. Samples were dried in an oven at $60^{\circ} \mathrm{C}$ and ground into small pieces $(\sim 1 \mathrm{~mm})$ with a laboratory type grinder. Elemental analysis of hazelnut shell was conducted via elemental analyzer (CHNS-932, Leco, USA). Moisture and ash contents of biomass were determined with Thermal Gravimetric Analysis (TGA-51, Shimadzu, Japan) [21]. Ultimate and proximate analyses of feedstock are shown in Table 1. Cellulose, hemicellulose and lignin contents of hazelnut shell (Table 1 ) were identified by using Van Soest Method [22,23]. The reagents used as standards for HPLC analysis are as follows: fructose ( $\geq 99 \%)$, pyruvic acid (98\%), glycolaldehyde, glycolic acid (99\%), glycerolaldehyde (99\%), levulinic acid (98\%), 5-HMF (99\%) and lactic acid (98\%) were obtained from Sigma-Aldrich and also, furfural (98\%), acetic acid (100\%), glucose $(\geq 99.5 \%)$ and formic acid (98-100\%) were purchased from Merck. Sulfuric acid (96-98\%) and phosphoric acid (85-90\%) were obtained from Merck and Fluka, respectively. For bioactivity tests, gallic acid (97.5\%), 6-hydroxy-2,5,7,8-tetramethylchromane-2-carboxylic acid (97\%), 2,2'-azino-bis(3-ethylbenzothiazoline-6-sulphonic acid (ABTS), sodium carbonate (99.5\%) and potassium persulfate (99.9\%) were purchased from Sigma-Aldrich and Folin-Ciocalteu's phenol reagent and ethanol were purchased from Merck. De-ionized water was used for preparing solutions in all experiments.

\subsection{Hydrothermal conversion in subcritical water}

The hydrothermal conversion of waste hazelnut shell in subcritical water was carried out in a batch reactor (Parr 5500 Series, USA) made of SS-316 with a $300 \mathrm{~mL}$ of total volume, $350{ }^{\circ} \mathrm{C}$ maximum temperature and 207 bar maximum pressure, as shown in Fig. 1. The reactor was initially loaded with $4 \mathrm{~g}$ of hazelnut shell and then the volume is completed to $100 \mathrm{~mL}$ by adding de-ionized water. For comparison, different concentration of acid $\left(\mathrm{H}_{2} \mathrm{SO}_{4}\right.$ and $\left.\mathrm{H}_{3} \mathrm{PO}_{4}\right)$ was placed at the same reaction conditions. Nitrogen gas was flowed to remove air inside the reactor, which then heated up to the desired reaction temperature with stirring rate of 200-250 rpm throughout the experiment. During heating period, temperature and internal pressure increased until reaching desired reaction temperature and reaction time started when temperature reached desired value. Required heating time to reach desired reaction temperature varies according to reaction temperature, for instance; $23 \mathrm{~min}, 30 \mathrm{~min}, 65 \mathrm{~min}$ and $73 \mathrm{~min}$ for $150{ }^{\circ} \mathrm{C}, 20{ }^{\circ} \mathrm{C}, 250{ }^{\circ} \mathrm{C}$ and $280^{\circ} \mathrm{C}$ (SI, Fig. S1), respectively. At the end of the reaction time, the heater was turned off and reactor was cooled by cooling water with

Table 1

Ultimate, proximate and structural analysis of hazelnut shell.

\begin{tabular}{ll}
\hline & Hazelnut shell \\
\hline Ultimate analysis (wt\%) & \\
$\mathrm{C}$ & 50.44 \\
$\mathrm{H}$ & 6.76 \\
$\mathrm{~N}$ & 0.76 \\
$\mathrm{~S}$ & 0.11 \\
$\mathrm{O}^{\mathrm{a}}$ & 41.92 \\
& \\
Proximate analysis (wt\%) & \\
Moisture & 8.93 \\
Ash & 1.48 \\
Protein & 3.11 \\
Structural analysis (wt\%) & \\
Cellulose & \\
Hemicellulose & 36.02 \\
Lignin & 12.66 \\
Extractives & 40.14 \\
\hline a Obtained from difference. & 7.86 \\
\hline
\end{tabular}

a Obtained from difference. 


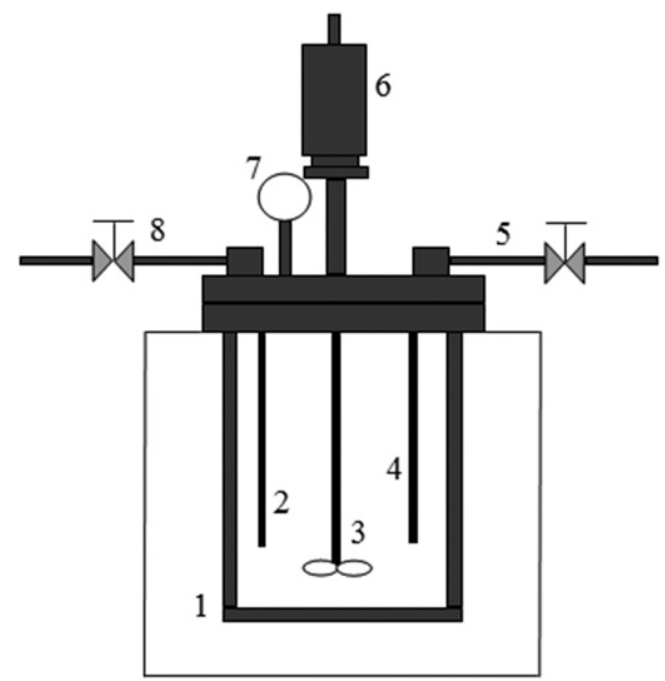

Fig. 1. Hydrothermal conversion reactor: (1) stainless steel vessel, (2) thermocouple, (3) stirring impeller, (4) gas inlet, (5) input nitrogen gas, (6) magnetically driven stirrer, (7) pressure gauge, (8) gas sample collector.

stirring until the temperature was reduced to $40^{\circ} \mathrm{C}$. After the reaction, liquid, solid and gaseous products were obtained. Gaseous product was collected into gas bags. Solid and liquid product was separated with a filter paper $(2-3 \mu \mathrm{mm})$ and the liquid product was defined as the water-soluble part (liquor). The remained solid residue was put in a forced oven to remove the moisture with set conditions as $50{ }^{\circ} \mathrm{C}$ for $24 \mathrm{~h}$ and then weighted. In this study, the reaction temperature and reaction time were varied at $150-280{ }^{\circ} \mathrm{C}$ and $15-120 \mathrm{~min}$, respectively. Different acid concentrations $(0,50,75,100$ and $125 \mathrm{mM})$ and types $\left(\mathrm{H}_{2} \mathrm{SO}_{4}\right.$ and $\left.\mathrm{H}_{3} \mathrm{PO}_{4}\right)$ were used.

\subsection{Analytical methods}

\subsubsection{Identification and characterization of products}

Liquid products were identified and quantified via HPLC (Agilent 1200, USA). The HPLC system equipped with Shodex Sugar Column (SH 1011) and refractive index detector (RID). Dilute sulfuric acid ( $3.75 \mathrm{mM}$ ) was used as a mobile phase with a flow rate of $0.5 \mathrm{~mL} / \mathrm{min}$ and the temperature of column was set $50{ }^{\circ} \mathrm{C}$ [24]. GC-MS (Agilent 6890 N/5973 N Network, USA) analysis with Restek Stabilwax-DA column and Agilent 5973 Mass Selective Detector (S/SL inlet) was used to verify the HPLC results. Helium at $1.3 \mathrm{~mL} / \mathrm{min}$ of flow rate was used as an eluent gas at $240{ }^{\circ} \mathrm{C}$ of operating temperature. Additionally, oven temperature programme is $40{ }^{\circ} \mathrm{C}\left(2 \mathrm{~min}\right.$ with an increase of $8{ }^{\circ} \mathrm{C} /$ min), $140{ }^{\circ} \mathrm{C}$ ( $5 \mathrm{~min}$ with an increase of $10{ }^{\circ} \mathrm{C} / \mathrm{min}$ ), and $220^{\circ} \mathrm{C}$ (10 min) [25]. Gas products were analyzed by Gas Chromatography equipped with Thermal Conductivity Detector (GC-TCD) (Agilent 6890 $\mathrm{N}$, USA). Restek Packed column ( $2 \mathrm{~m}$ long $\times 2 \mathrm{~mm}$ i.d.) with TCD detector with $250{ }^{\circ} \mathrm{C}$ of detector temperature was used. $20 \mathrm{~mL} / \mathrm{min}$ of flow rate of helium was used as a mobile phase. In addition, oven temperature programme is $50{ }^{\circ} \mathrm{C}$ for $3 \mathrm{~min}, 100{ }^{\circ} \mathrm{C}$ ( $5 \mathrm{~min}$ with an increase of $\left.50{ }^{\circ} \mathrm{C} / \mathrm{min}\right), 200{ }^{\circ} \mathrm{C}\left(5 \mathrm{~min}\right.$ with an increase of $\left.50{ }^{\circ} \mathrm{C} / \mathrm{min}\right)$ and $250{ }^{\circ} \mathrm{C}$ ( $7 \mathrm{~min}$ with an increase of $50^{\circ} \mathrm{C} / \mathrm{min}$ ) [25]. Solid morphology and functional groups of untreated waste hazelnut shell and solid residues were examined by Scanning Electron Microscopy with Energy Dispersive XRay Analysis (SEM-EDX) (Quanta 250 SEM, USA) and Fourier Transform Infrared Spectrometry equipped with attenuated total reflectance (ATRFTIR) (Perkin Elmer-Spectra Two, USA), respectively. The total organic carbon in the solid product was determined by TOC analyzer (TOCVCPH, Shimadzu, Japan). Hazelnut shell conversion (Eq. (1)) and TOC conversion (Eqs. (2) and (3)) were calculated with respect to initial weight of hazelnut shell and initial TOC amount of hazelnut shell, respectively. Selectivity of compound was calculated according to concentration of produced product and initial concentration of hazelnut shell $(40,000 \mathrm{ppm})$, which was calculated with initial weight of hazelnut shell $(4 \mathrm{~g})$ and volume of water $(100 \mathrm{~mL})$, in the aqueous reaction solution (Eq. (4)).

Conversion $(\%)=\frac{\text { Initial amount of biomass }(\mathrm{g})-\text { Residual amount of solid product }(\mathrm{g})}{\text { Initial amount of hazelnut shell }(\mathrm{g})}$ $\times 100$

Total organic carbon $(\mathrm{TOC})=$ Total carbon $(\mathrm{TC})$ - Inorganic carbon (IC)

TOC Conversion $(\%)=\frac{\text { Initial TOC amount of biomass }(\mathrm{mg})-\text { TOC amount of solid product }(\mathrm{mg})}{\text { Initial TOC amount of biomass }(\mathrm{mg})}$ $\times 100$

Selectivity $(\%)=\frac{\text { Concentration of produced product }(\mathrm{ppm})}{\text { Initial concentration of biomass in reaction solution }(\mathrm{ppm})} \times 100$

\subsubsection{Total phenolic content}

The total phenolic content in aqueous solution was determined according to the Folin-Ciocalteu's method. Folin Ciocalteu reagent was diluted 10 -fold with distilled water and $7.5 \%$ ( $75 \mathrm{~g} / \mathrm{L}$ ) of sodium carbonate solution was prepared with distilled water. $0.5 \mathrm{~mL}$ of Folin Ciocalteu reagent, $0.5 \mathrm{~mL}$ of liquid product and $1 \mathrm{~mL}$ of saturated sodium carbonate solution were mixed and then volume adjusted to $10 \mathrm{~mL}$ with distilled water. After mixing, the mixture was left in the dark at room temperature for $45 \mathrm{~min}$. The absorbance was measured at $725 \mathrm{~nm}$ with using water as a blank. The phenolic contents were expressed as milligrams of gallic acid equivalents (GAE) per milliliter of aqueous solution [26].

\subsubsection{Total antioxidant capacity}

The antioxidant capacity in liquid product was determined using ABTS method. ABTS radical $\left(\mathrm{ABTS}^{+}\right)$solution was prepared by $14 \mathrm{mM}$ ABTS solution and $4.9 \mathrm{mM}$ potassium persulfate solution with the volume ratio of $1: 1$ and left for $16 \mathrm{~h}$ at dark room. After $16 \mathrm{~h}, \mathrm{ABTS}^{+}$solution was diluted with ethanol with the volume ratio of 1:50 (ABTS ${ }^{+}$ solution:ethanol). Then, $1 \mathrm{~mL}$ of liquid product was mixed with $4 \mathrm{~mL}$ of $\mathrm{ABTS}^{+}$solution and left in the dark at room temperature for $5 \mathrm{~min}$. The absorbance was measured at $734 \mathrm{~nm}$ and water was used as blank. The antioxidant capacity was expressed as milligrams of trolox equivalents (TE) per milliliter of liquid products [26].

\section{Results and discussion}

Main identified components were levulinic acid, acetic acid and furfural after hydrothermal degradation of waste hazelnut shell in hot compressed water. The effects of reaction temperature, acid concentration or type $\left(\mathrm{H}_{2} \mathrm{SO}_{4}\right.$ and $\left.\mathrm{H}_{3} \mathrm{PO}_{4}\right)$ and reaction time were investigated. The typical reflective index (RI) and GC-MS chromatograms are shown in Fig. 2.

\subsection{Effect of reaction temperature}

Experiments were conducted with varying reaction temperatures from 150 to $280^{\circ} \mathrm{C}$ in the presence of $50 \mathrm{mM} \mathrm{H}_{2} \mathrm{SO}_{4}$ concentration to understand the influence of reaction temperature on the conversion of waste hazelnut shell and the product selectivities. Experimental results of conversions of TOC and waste hazelnut shell and the liquid product selectivities are given in Table 2.

As illustrated in Table 2, the conversion of waste hazelnut shell increased with increasing reaction temperature at each reaction time. When the reaction was carried out at $280^{\circ} \mathrm{C}$, hazelnut shell conversion reached to maximum level with a value of $65.40 \%$ at $120 \mathrm{~min}$. The conversion of hazelnut shell remained stable with the increment of reaction 



Fig. 2. a) RI and b) GC-MS chromatograms of liquid products after hydrothermal degradation of hazelnut shell $\left(200{ }^{\circ} \mathrm{C}, 60 \mathrm{~min}, 15\right.$ bar of final pressure and with 50 mM $\left.\mathrm{H}_{2} \mathrm{SO}_{4}\right)$.

time. On the other hand, no significant differences observed between the conversions of TOC and hazelnut shell under same conditions. When the hydrothermal conversion was conducted for different reaction times, the TOC conversion was enhanced and reached to $47.92 \%$ $\left(280{ }^{\circ} \mathrm{C}\right)$ from $32.61 \%\left(150^{\circ} \mathrm{C}\right)$ at the end of $120 \mathrm{~min}$.
Mainly, we focused on the generation of levulinic acid, acetic acid and furfural production from waste hazelnut shell. The yield of fructose was quite higher at lower temperature $\left(150^{\circ} \mathrm{C}\right)$ whereas no levulinic acid formation was observed until 90 min since cellulose firstly hydrolyzed into glucose and then isomerized to fructose [27]. Under higher

Table 2

Experimental results of various reaction temperatures with $50 \mathrm{mM}$ initial sulfuric acid concentration.

\begin{tabular}{|c|c|c|c|c|c|c|c|}
\hline \multirow[t]{2}{*}{$\mathrm{T}\left({ }^{\circ} \mathrm{C}\right)$} & \multirow[t]{2}{*}{$\mathrm{t}(\mathrm{min})$} & \multirow[t]{2}{*}{ Nut conversion (\%) } & \multirow[t]{2}{*}{ TOC conversion (\%) } & \multicolumn{4}{|c|}{ Product Selectivity \% } \\
\hline & & & & Fructose & Levulinic acid & Acetic acid & Furfural \\
\hline \multirow[t]{4}{*}{150} & 15 & 35.79 & 29.59 & 41.96 & 0 & 11.58 & 1.54 \\
\hline & 60 & 41.42 & 38.49 & 47.74 & 0 & 9.53 & 5.54 \\
\hline & 90 & 42.14 & 35.01 & 43.11 & 0.10 & 11.09 & 6.60 \\
\hline & 120 & 41.12 & 32.61 & 34.94 & 0.28 & 10.97 & 11.91 \\
\hline \multirow[t]{4}{*}{200} & 15 & 56.99 & 47.73 & 1.13 & 6.85 & 8.66 & 13.09 \\
\hline & 60 & 59.32 & 45.87 & 0.58 & 13.33 & 8.43 & 7.73 \\
\hline & 90 & 61.20 & 46.08 & 0.50 & 12.45 & 8.09 & 5.32 \\
\hline & 120 & 58.39 & 46.96 & 1.24 & 13.01 & 8.68 & 5.72 \\
\hline \multirow[t]{4}{*}{250} & 15 & 61.66 & 46.52 & 1.08 & 10.91 & 8.05 & 0.92 \\
\hline & 60 & 61.44 & 47.30 & 0.91 & 10.21 & 7.80 & 0.39 \\
\hline & 90 & 61.02 & 45.04 & 1.09 & 10.87 & 8.72 & 0.22 \\
\hline & 120 & 61.07 & 47.41 & 1.07 & 13.26 & 7.89 & 0.21 \\
\hline \multirow[t]{4}{*}{280} & 15 & 62.54 & 43.39 & 0.48 & 8.42 & 8.28 & 0.25 \\
\hline & 60 & 64.64 & 49.71 & 0.35 & 11.85 & 8.09 & 0.18 \\
\hline & 90 & 64.39 & 48.26 & 0.28 & 13.26 & 8.78 & 0.07 \\
\hline & 120 & 65.40 & 47.92 & 0.11 & 13.05 & 8.76 & 0.04 \\
\hline
\end{tabular}


temperature treatment, the amount of fructose decreased down to $0.11 \%\left(280{ }^{\circ} \mathrm{C}\right.$ and $\left.120 \mathrm{~min}\right)$ thus, this decrement resulted in the enhancement of levulinic acid production. This phenomenon can be explained by structural changes of water with increasing temperature. If reaction temperature is improved to near critical point of water, the hydrogen bonds start to weaken and become less stable which enhances the solubility of non-polar organics and increases diffusivity by decreasing density of water [6,9]. Moreover, low dielectric constant and high self-dissociation lead to boost ionic reaction [8]. In contrast to levulinic acid selectivity, relatively lower reaction temperature seemed more workable condition for the production of furfural in subcritical water because of low thermal stability of hemicellulose [10]. When reaction temperature was increased, the rate of formation of furfural significantly decreased and recorded as $0.04 \%$ at $280^{\circ} \mathrm{C}$ and $120 \mathrm{~min}$. In the case of acetic acid, selectivity was slightly higher at $150{ }^{\circ} \mathrm{C}$, but this value was quite stable at higher temperature treatment. Furthermore, organic acid formation during treatment can be conclude from $\mathrm{pH}$ values since the $\mathrm{pH}$ of liquid product altered through acidic condition $(\mathrm{pH} 3.27$ at $280^{\circ} \mathrm{C}$ ) from neutral with hydrothermal treatment. Therefore, this demonstrates that sugars decompose into various organic acids which cause to autocatalysis [14].

Ultimately, temperature affects either the rate of degradation or reaction mechanisms. During hydrothermal conversion, two reaction mechanisms are dominant which are ionic reaction and free radical reaction. While ionic reaction is promoted by lower temperatures due to high ionic product $\left(K_{w}>10^{-14}\right)$, free radical reaction favors under higher temperatures $[6,9,28]$. In addition, radicals such as $\mathrm{OH}^{\bullet}$, as the strongest oxidant, decompose swiftly in subcritical water [29]. Therefore, ionic reactions were superior under the hydrothermal conversion of waste hazelnut shell.

As stated before we obtained liquid, solid and gaseous products. In the case of solid compound, SEM-EDX, elemental, FTIR and TOC analyses were performed to identify the structure and content of solid residues after hydrothermal treatment. Solid residue, biochar, is a product that has higher heating value and high amount of $C$. Studies of biochar valorization have been performed in the field of solid fuels [30-32], adsorbents [33-36], fertilizer [37,38], material of soil amendment [33,39, 40], carbon black [41-43] and carbon sequestration [40,43-45]. The SEM-EDX images to monitor changes on the surface structure of untreated hazelnut shell as well as solid residues of each treatment conditions are shown in Fig. 3. The structure of hazelnut shell is found in complex layer with fibers (Fig. 3a). After the hydrothermal reaction with $50 \mathrm{mM} \mathrm{H}_{2} \mathrm{SO}_{4}$ at $150{ }^{\circ} \mathrm{C}$ in subcritical water, the complex raw material structure started to be broken down and small carbon spheres were observed (Fig. 3b). This phenomenon suggests that the cellulose and hemicellulose structures of raw material easily decomposed due to higher diffusivity of water under subcritical water condition [12]. At $250{ }^{\circ} \mathrm{C}$ and $280^{\circ} \mathrm{C}$, the amount of carbon spheres decreased with the particle size of approximately 1-2 $\mu \mathrm{m}$ and found in tarry structures (Fig. 3c-d). The presence of carbon in solid residues was revealed with SEM-EDX (Table 3 and Fig. 3d), elemental analysis (Table 4) and TOC analysis. With regard to reaction temperature, higher $\mathrm{C}$ amount was

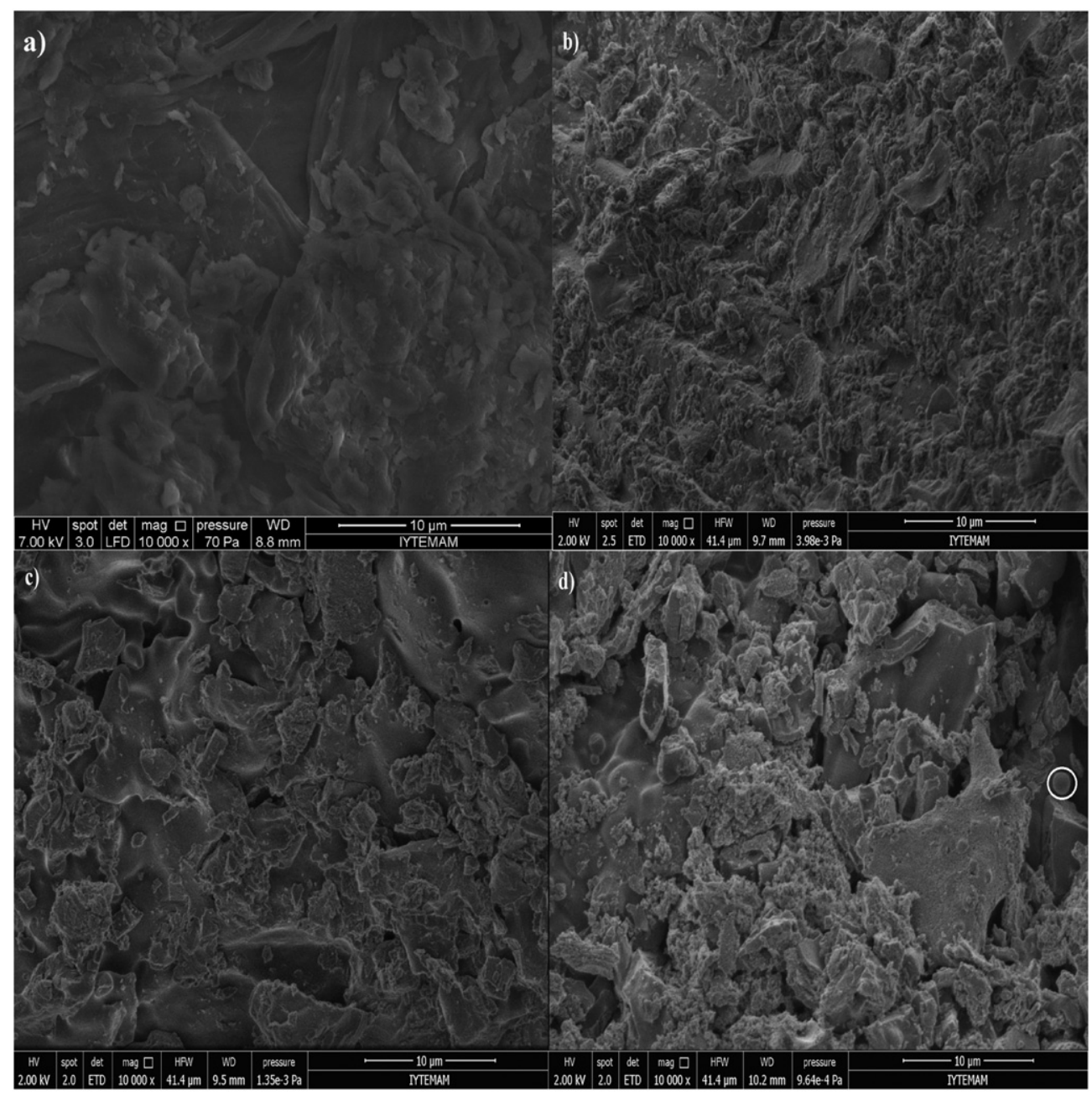

Fig. 3. SEM-EDX images of a) untreated and solid residues after the treatment at b) $150{ }^{\circ} \mathrm{C}$; c) $250{ }^{\circ} \mathrm{C}$; d) $280{ }^{\circ} \mathrm{C}$ after 60 min and with $50 \mathrm{mM} \mathrm{H}_{2} \mathrm{SO} \mathrm{O}_{4}$ (at magnification of $\times 10,000$ ). 
Table 3

SEM-EDX results of solid residues at different reaction temperature (60 min and $50 \mathrm{mM}$ $\mathrm{H}_{2} \mathrm{SO}_{4}$ ).

\begin{tabular}{llll}
\hline Temperature $\left({ }^{\circ} \mathrm{C}\right)$ & $\mathrm{C}($ wt $\%)$ & $\mathrm{O}($ wt $\%)$ & $\mathrm{S}($ wt $\%)$ \\
\hline 150 & 59.34 & 40.35 & 0.18 \\
200 & 67.26 & 32.38 & 0.16 \\
250 & 71.53 & 26.48 & 0.44 \\
280 & 72.97 & 25.68 & 0.60 \\
\hline
\end{tabular}

Table 4

Elemental analysis results of solid residues at different reaction temperature (60 min and $50 \mathrm{mM} \mathrm{H}_{2} \mathrm{SO}_{4}$ ).

\begin{tabular}{llllll}
\hline Temperature $\left({ }^{\circ} \mathrm{C}\right)$ & $\mathrm{C}(\mathrm{wt} \%)$ & $\mathrm{H}(\mathrm{wt} \%)$ & $\mathrm{N}(\mathrm{wt} \%)$ & $\mathrm{S}(\mathrm{wt} \%)$ & $\mathrm{O}^{\mathrm{a}}(\mathrm{wt} \%)$ \\
\hline 150 & 51.03 & 5.75 & 0.78 & 0.56 & 41.88 \\
200 & 59.97 & 4.99 & 1.03 & 0.43 & 33.58 \\
250 & 49.83 & 4.57 & 0.53 & 0.44 & 44.63 \\
280 & 56.72 & 4.02 & 0.68 & 0.50 & 38.08 \\
\hline
\end{tabular}

a Obtained from difference.

achieved due to repolymerization while $\mathrm{O}$ amount of residues decreased because of oxygenated chemical formation.

The FTIR spectrometry of untreated and treated hazelnut shell residues after subcritical water treatment at different reaction temperatures $\left(150,200\right.$ and $\left.280{ }^{\circ} \mathrm{C}\right)$ are presented in Fig. 4. The bands at $1030 \mathrm{~cm}^{-1}, 1375 \mathrm{~cm}^{-1}$ and $2980 \mathrm{~cm}^{-1}$ are typical cellulose and hemicellulose structure $[12,46]$ that are associated with $\mathrm{C}-\mathrm{O}$ stretching of alcohols, carboxylic acids and esters, $\mathrm{C}-\mathrm{H}$ bending of alkanes and saturated aliphatic $\mathrm{C}-\mathrm{H}$ stretching, respectively. The peaks of raw hazelnut shell at $1375 \mathrm{~cm}^{-1}$ and $2980 \mathrm{~cm}^{-1}$ were sharper than those of the hydrothermally treated solid residues. Additionally, the peak at $1375 \mathrm{~cm}^{-1}$ disappeared at $280^{\circ} \mathrm{C}$. This indicates that cellulosic and hemicellulosic structure of hazelnut shell decomposed under higher temperature treatment. The bands at $1215-1275 \mathrm{~cm}^{-1}$ are assigned to stretching of aliphatic $\mathrm{C}-\mathrm{H}$ groups. Furthermore, absorption peaks at $1600 \mathrm{~cm}^{-1}$ and $3330 \mathrm{~cm}^{-1}$ are attributed stretching of $\mathrm{C}=\mathrm{C}$ aromatic groups and hydrogen bonded $\mathrm{O}-\mathrm{H}$, respectively. These peaks correspond to characteristic lignin structure $[12,47]$. The presence of these lignin structures can be identified in each case. This suggests that the
Table 5

Distribution of gaseous compounds for $250{ }^{\circ} \mathrm{C}$ and $280{ }^{\circ} \mathrm{C}, 120 \mathrm{~min}$ and $50 \mathrm{mM} \mathrm{H}_{2} \mathrm{SO}_{4}$

\begin{tabular}{lllllllll}
\hline Temperature $\left({ }^{\circ} \mathrm{C}\right)$ & \multicolumn{8}{l}{ Gas composition $(\mu \mathrm{g} / \mathrm{mL})$} \\
\cline { 2 - 9 } & $\mathrm{H}_{2}$ & $\mathrm{CO}$ & $\mathrm{CH}_{4}$ & $\mathrm{CO}_{2}$ & $\mathrm{C}_{2} \mathrm{H}_{4}$ & $\mathrm{C}_{2} \mathrm{H}_{6}$ & $\mathrm{C}_{3} \mathrm{H}_{6}$ & $\mathrm{C}_{3} \mathrm{H}_{8}$ \\
\hline 250 & 2.77 & 160.28 & 0.29 & 637.26 & 0.20 & 0.06 & 0.57 & 0 \\
280 & 1.42 & 200.47 & 1.78 & 591.12 & 0.36 & 0.65 & 1.25 & 0.32
\end{tabular}

cleavage of phenolic and alcoholic bonds is still difficult even operating at higher temperatures [47].

The secondary decomposition reactions of water-soluble compounds of hazelnut shell are favored at relatively higher temperature that resulted in more gas products production. Therefore, in our study, the gas product distribution was determined via gas chromatography thermal conductivity detector at $250^{\circ} \mathrm{C}$ and $280^{\circ} \mathrm{C}, 120 \mathrm{~min}$ in the presence of $50 \mathrm{mM} \mathrm{H}_{2} \mathrm{SO}_{4}$ (SI, Fig. S2). The major identified gas compounds after the hydrothermal conversion of hazelnut shell were carbon monoxide and carbon dioxide and also, trace amounts of hydrogen gas and methane (Table 5). It is known that high carbon monoxide and carbon dioxide concentrations arise from decarbonylation of aldehydes and decarboxylation of carboxylic acids, respectively [12]. As the reaction temperature increased from $250{ }^{\circ} \mathrm{C}$ to $280{ }^{\circ} \mathrm{C}$, selectivity of formic acid decreased from $0.18 \%$ to $0.04 \%$ due to the dehydration of formic acid into carbon monoxide under subcritical water $\left(300{ }^{\circ} \mathrm{C}\right)[23,48,49]$, thus; carbon monoxide amount increased from 160.28 to 200.47 $\mu \mathrm{g} / \mathrm{mL}$. On the contrary, there was a decrement in carbon dioxide concentration from 637.26 to $591.12 \mu \mathrm{g} / \mathrm{mL}$. This behavior indicates that water gas shift reaction [48] shifts through left-hand side towards carbon monoxide when the reaction temperature increased. Compared to other compounds, remarkable low hydrogen gas concentration was observed which decreased from $2.77 \mu \mathrm{g} / \mathrm{mL}\left(250{ }^{\circ} \mathrm{C}\right)$ to $1.42 \mu \mathrm{g} / \mathrm{mL}$ $\left(280^{\circ} \mathrm{C}\right)$ as a result of interaction between cellulose and xylan with lignin which reduce hydrogen gas generation by donating $\mathrm{H}$ atom to lignin [50]. The concentration of methane increased from 0.29 to $1.78 \mu \mathrm{g} / \mathrm{mL}$ with the increment of reaction temperature.

\subsection{Effect of acid addition}

As studied before $[13,14,51]$, the presence of acid shows positive effect on the hydrothermal degradation of biomass. Acid addition enables

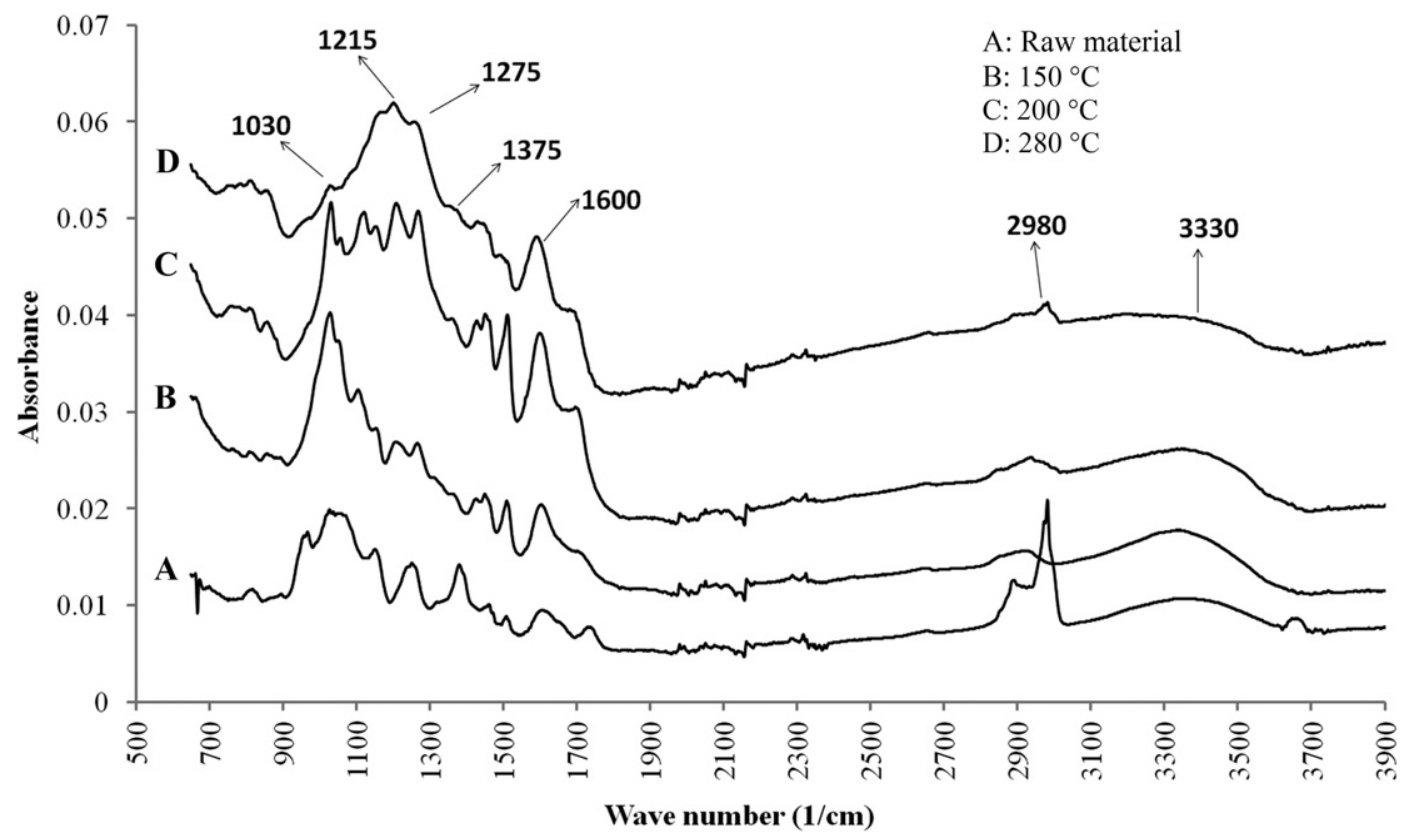

Fig. 4. FTIR spectrum of untreated and treated hazelnut shell samples at different temperatures (60 min and with $\left.50 \mathrm{mM} \mathrm{H}_{2} \mathrm{SO}_{4}\right)$. 
relatively not only high product selectivity but also lower operation conditions that reduce energy cost. Therefore, $\mathrm{H}_{2} \mathrm{SO}_{4}$ and $\mathrm{H}_{3} \mathrm{PO}_{4}$ were preferred to investigate the influence of acid addition on the conversion of hazelnut shell and liquid product distribution. All experiments were conducted at $200{ }^{\circ} \mathrm{C}$ and $60 \mathrm{~min}$ reaction time to eliminate corrosion problems of high temperature and high pressure system in acidic condition although high reaction temperature has a significant effect on the product selectivities. The selectivities of liquid products obtained from the decomposition of waste hazelnut shell in hot compressed water are shown in Fig. 5.

The level of hazelnut shell conversion in the presence of $\mathrm{H}_{3} \mathrm{PO}_{4}$ was relatively lower than it was with $\mathrm{H}_{2} \mathrm{SO}_{4}$. While the conversion of hazelnut shell increased up to $61.05 \%$ in the presence of $75 \mathrm{mM} \mathrm{H}_{2} \mathrm{SO}_{4}$ then decreased slightly to $58.94 \%$ with the addition of more $\mathrm{H}_{2} \mathrm{SO}_{4}$, conversion was improved continuously and reached to $56.38 \%$ with $125 \mathrm{mM}$ $\mathrm{H}_{3} \mathrm{PO}_{4}$. As illustrated in Fig. 5, both acid types influenced distinctly to the liquid product distribution. The yield of 5-HMF in the $\mathrm{H}_{3} \mathrm{PO}_{4}$ was higher than that of $\mathrm{H}_{2} \mathrm{SO}_{4}$. This can be clarified by easy dehydration of highly reacting species like glucose in the small amount of acid [13]. Therefore, using relatively weaker acid like $\mathrm{H}_{3} \mathrm{PO}_{4}$ increases the amount of 5-HMF. On the other hand, using a strong acid such as $\mathrm{H}_{2} \mathrm{SO}_{4}$ enhances the transformation of 5-HMF into levulinic acid. Compared to $\mathrm{H}_{3} \mathrm{PO}_{4}$, the formation of levulinic acid was significant in the presence of $\mathrm{H}_{2} \mathrm{SO}_{4}$. As adding more $\mathrm{H}_{2} \mathrm{SO}_{4}$ to the reaction solution, selectivity of levulinic acid greatly enhanced and reached to $15.40 \%$, whereas it was quite low (3.07\%) with $125 \mathrm{mM} \mathrm{H}_{3} \mathrm{PO}_{4}$. On the contrary, weaker acid was observed as more favorable for the production of furfural since the selectivity of furfural in the presence of $\mathrm{H}_{3} \mathrm{PO}_{4}$ increased up to $16.74 \%$ ( $100 \mathrm{mM})$, but decreased linearly to $3.62 \%$ in the case of adding $100 \mathrm{mM}$ of $\mathrm{H}_{2} \mathrm{SO}_{4}$. This reverse trend might be explained by two phenomena: First one is that furfural can be converted to char by polymerization of furfural [52]. Second one is the structure of lignocellulosic biomass. The structure of hemicellulose is non-uniform and has low crystallinity because of having high amount of side chains so the decomposition of hemicellulose can be readily exist under the temperature range of $210-330^{\circ} \mathrm{C}$. On the other hand, unbranched glucose units of cellulose cause high degree of crystallinity [10]. In the case of acetic acid, the selectivities did not show notable difference in the presence of $\mathrm{H}_{2} \mathrm{SO}_{4}$ and $\mathrm{H}_{3} \mathrm{PO}_{4}$.

\subsection{Effect of reaction time}

After hydrothermal degradation of hazelnut shell with $50 \mathrm{mM} \mathrm{H}_{2} \mathrm{SO}_{4}$ at $200^{\circ} \mathrm{C}$, it was observed that reaction time did not affect as much as reaction temperature and acid addition to hazelnut shell conversion and acetic acid selectivity (SI, Fig. S3). As reaction proceeded from 15 to $120 \mathrm{~min}, 2.43 \%$ of 5 -HMF selectivity decreased to nearly zero. However, under same conditions, levulinic acid selectivity reached to $13.01 \%$ with a longer treatment (120 min). This indicates that after longer reaction time, the rate of 5-HMF rehydration was enhanced and further converted into levulinic acid. Moreover, low reaction time was effective for
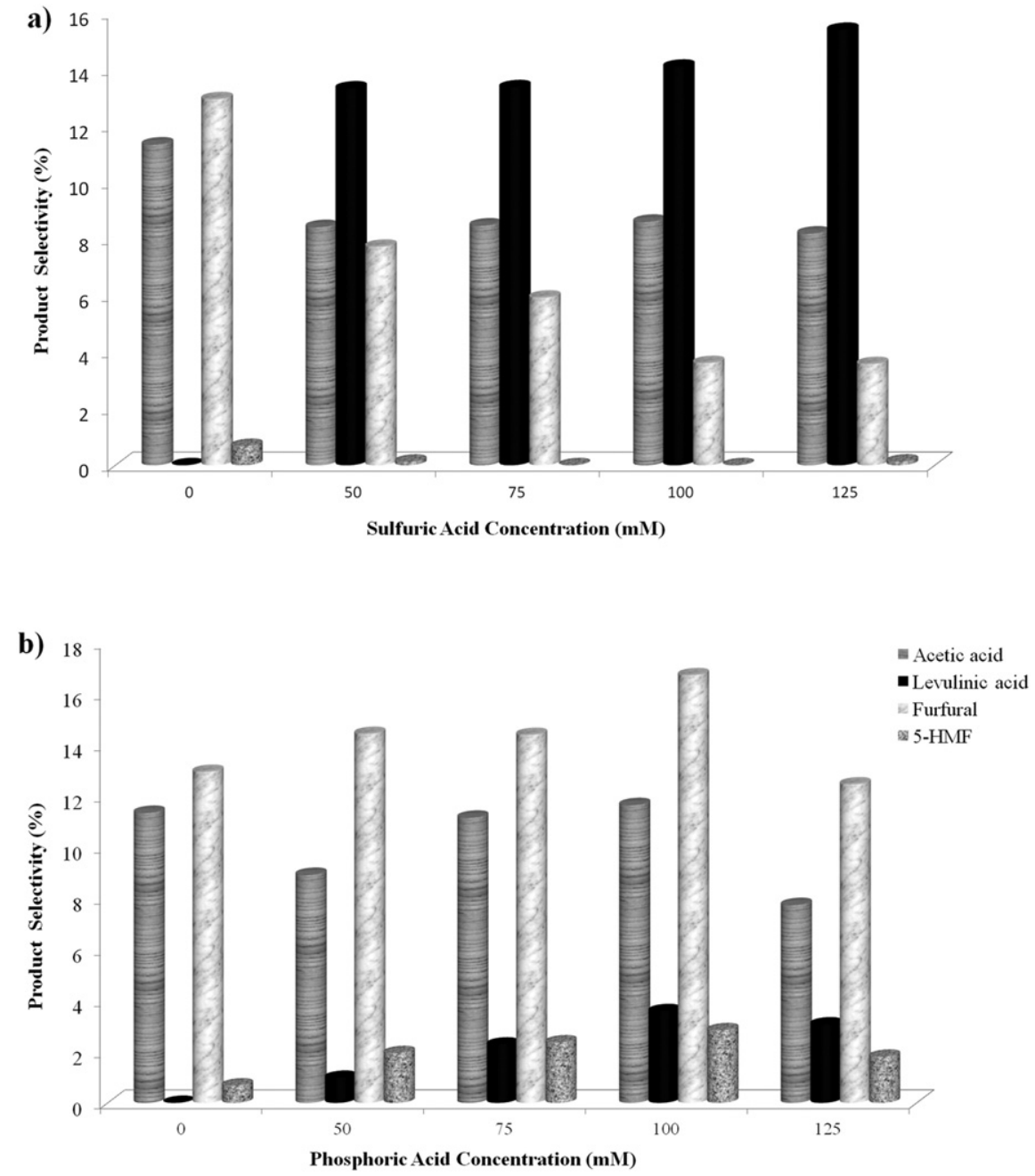

Fig. 5. Effect of acid addition on the product selectivities at $200{ }^{\circ} \mathrm{C}, 60 \mathrm{~min}$ and 15 bar of final pressure with a) $\mathrm{H}_{2} \mathrm{SO}_{4}$, and b) $\mathrm{H}_{3} \mathrm{PO}_{4}$. 
the production of furfural and as reaction time increased, furfural selectivity decreased significantly from $13.09 \%$ (15 $\mathrm{min}$ ) to 5.72\% (120 $\mathrm{min}$ ).

\subsection{Possible reaction pathways of hydrothermal conversion of hazelnut shell}

According to those results, main reaction mechanisms of the hydrothermal conversion of waste hazelnut shell at different reaction temperatures were suggested, as illustrated in Table 6. Under subcritical water media, the rate of cellulose hydrolization to oligomers [16] and isomerization of glucose into fructose [16] were rapid at low temperature $\left(150{ }^{\circ} \mathrm{C}\right)$. At $200{ }^{\circ} \mathrm{C}$, the production of $5-\mathrm{HMF}$ became more favorable with the addition of higher $\mathrm{H}_{3} \mathrm{PO}_{4}$ concentration $(75-100 \mathrm{mM})$. Furthermore, the rate of rehydration of 5-HMF into levulinic acid was enhanced in excess amount of $\mathrm{H}_{2} \mathrm{SO}_{4}(100-125 \mathrm{mM})$ and long reaction time ( $\geq 60 \mathrm{~min}$ ). In the case of hemicellulose, two main reaction pathways were possible: when hydrothermal reaction was performed at low $\mathrm{H}_{2} \mathrm{SO}_{4}$ concentration $(0-5 \mathrm{mM})$ or high $\mathrm{H}_{3} \mathrm{PO}_{4}$ concentration (75-100 mM) at $200{ }^{\circ} \mathrm{C}$, acetic acid formation was favored by the cleavage of acetyl [16]. On the contrary, the pathway of furfural production dominated at $200{ }^{\circ} \mathrm{C}$ and $15 \mathrm{~min}$ in the presence of $50 \mathrm{mM} \mathrm{H}_{2} \mathrm{SO}_{4}$. Applying relatively higher reaction temperatures $\left(250-280^{\circ} \mathrm{C}\right)$ led to the transformation of furfural to char with longer reaction time.

\subsection{Bioactivity properties}

Agricultural wastes (i.e. hazelnut shell), which are natural products, contain a considerable amount of phenolic antioxidants such as gallic acid, ferulic acid, caffeic acid, sinapic acid, vanillic acid and p-coumaric acid. These compounds are beneficial in the case of cardiovascular disease and tissue injuries [53,54]. Although having high antioxidant capacity solution is not the main target for this study, while trying to obtain high selectivity of levulinic acid from waste hazelnut shell under hydrothermal conditions, it was also examined whether the final product solution showed antioxidant activity or not even at such high temperature and pressure conditions. The bioactivity properties including antioxidant activity and total phenolic content of liquid products obtained by the hydrothermal conversion of hazelnut shell in

Table 6

Main proposed reaction pathways for hydrothermal conversion of waste hazelnut shell at different reaction temperatures.

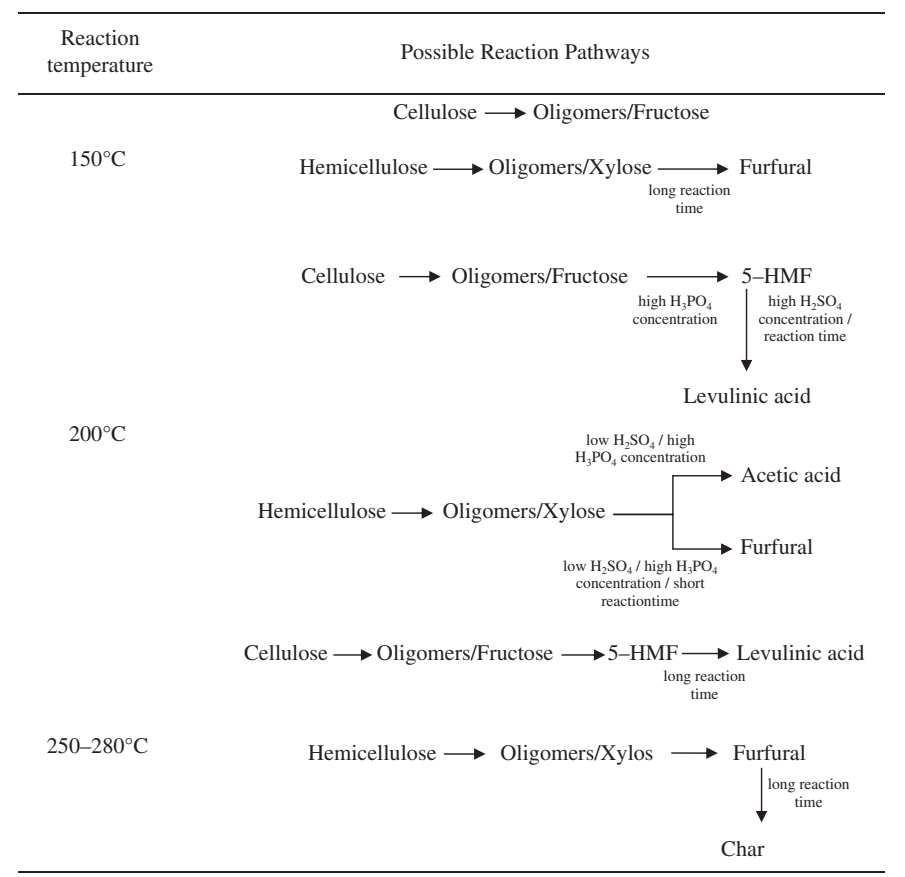

subcritical water were determined with ABTS method and FolinCiocalteu's method, respectively. The bioactivity properties were examined for $150-280^{\circ} \mathrm{C}$ reaction temperature range and $50-125 \mathrm{mM}$ acid $\left(\mathrm{H}_{2} \mathrm{SO}_{4}\right.$ and $\left.\mathrm{H}_{3} \mathrm{PO}_{4}\right)$ concentrations at 60 min reaction time.

Before the hydrothermal treatment, $0.00019 \mathrm{mg} \mathrm{TE} / \mathrm{mL}$ of antioxidant activity and $0 \mathrm{mg} \mathrm{GAE} / \mathrm{mL}$ of total phenolic content were determined, as blank experiments. With the effects of temperature and $\mathrm{H}_{2} \mathrm{SO}_{4}$ and $\mathrm{H}_{3} \mathrm{PO}_{4}$ treatments, antioxidative and phenolic compounds of hazelnut shell form in liquid product. Fig. 6 indicates the effect of reaction temperature on the antioxidant activity and total phenolic content in the presence of $\mathrm{H}_{2} \mathrm{SO}_{4}$. The antioxidant activity with the treatment of dilute sulfuric acid decreased from 0.045 to $0.038 \mathrm{mg}$ of $\mathrm{TE} / \mathrm{mL}$ when the reaction temperature increased to $280{ }^{\circ} \mathrm{C}$. This can be attributed to antioxidative products which are produced with the cleavage of H-bonds of hazelnut shell, were degraded under long reaction temperature treatment [55]. In addition, total phenolic content increased linearly and reached the maximum value $(0.095 \mathrm{mg}$ of $\mathrm{GAE} / \mathrm{mL})$ under $250{ }^{\circ} \mathrm{C}$ and $60 \mathrm{~min}$ with $50 \mathrm{mM} \mathrm{H}_{2} \mathrm{SO}_{4}$, then reduced to $0.062 \mathrm{mg}$ of $\mathrm{GAE} / \mathrm{mL}$ at $280{ }^{\circ} \mathrm{C}$. Meillisa et al. [56] stated that $4.0 \mathrm{mg} / \mathrm{mL}$ and $9.0 \mathrm{mg} / \mathrm{mL}$ of total phenolic content from purified alginate hydrolysate and S. japonica hydrolysate samples were obtained at $200{ }^{\circ} \mathrm{C}$ and $17 \mathrm{bar}$ with catalyst (formic acid), respectively.

The antioxidant activity slightly changed for both acid types with an increase in the acid concentrations. For each acid concentration and type, the antioxidant activity was recorded approximately as $0.045 \mathrm{mg}$ of TE/mL (SI, Fig. S4 and SI, Fig. S5). In the case of total phenolic content of the liquid product solution, different trends were observed for both $\mathrm{H}_{2} \mathrm{SO}_{4}$ and $\mathrm{H}_{3} \mathrm{PO}_{4}$ treatments. Total phenolic content decreased steadily in the presence of $\mathrm{H}_{2} \mathrm{SO}_{4}$, whereas it reached to $0.062 \mathrm{mg}$ of $\mathrm{GAE} / \mathrm{mL}$ with the addition of $125 \mathrm{mM} \mathrm{H}_{3} \mathrm{PO}_{4}$ (SI, Fig. S4 and SI, Fig. S5). These results may be arising from the different acidity levels of the aqueous solutions.

\subsection{Analysis of Variance (ANOVA)}

Statistical analysis of reaction temperature, $\mathrm{H}_{2} \mathrm{SO}_{4}$ concentration and reaction time for hazelnut shell conversion, the selectivities of levulinic acid, acetic acid and furfural were investigated in order to evaluate the significance of results by Analysis of Variance (ANOVA) with using MINITAB 16 software. The p-values of individual parameters ( $\mathrm{p} \leq$ 0.05 ) are shown to verify the significance of parameters, as seen in Table 7 and SI, Table S1. In addition, histogram plots of hazelnut shell conversion (SI, Fig. S6) and levulinic acid (SI, Fig. S7) are given in order to confirm the model accuracy.

ANOVA results of hazelnut shell conversion showed that the individual effects of reaction temperature and $\mathrm{H}_{2} \mathrm{SO}_{4}$ concentration and quadratic reaction temperature were significant with p-values of 0.00 , 0.10 and 0.00 , respectively. However, reaction time had no significant individual effect on the conversion of hazelnut shell due to having higher p-value (0.289) than confidence interval. In the case of product

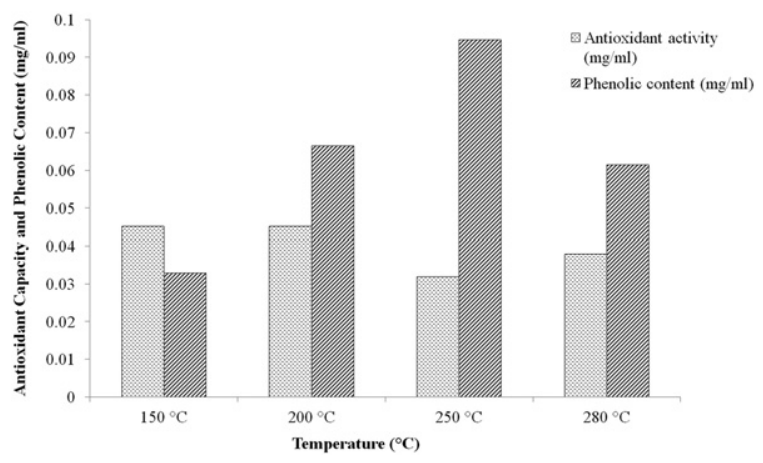

Fig. 6. Effects of reaction temperature on the antioxidant capacity and the total phenolic content with $50 \mathrm{mM} \mathrm{H}_{2} \mathrm{SO}_{4}$ after $60 \mathrm{~min}$. 
Table 7

Statistical analysis results of hazelnut shell conversion and levulinic acid.

\begin{tabular}{|c|c|c|c|c|c|}
\hline Source & $\mathrm{DF}$ & $\begin{array}{l}\text { Sum of } \\
\text { squares }\end{array}$ & $\begin{array}{l}\text { Mean of } \\
\text { squares }\end{array}$ & $\begin{array}{l}\mathrm{F} \\
\text { value }\end{array}$ & $\begin{array}{l}\mathrm{p} \\
\text { value }\end{array}$ \\
\hline \multicolumn{6}{|l|}{ Conversion } \\
\hline Model & 4 & 1586.77 & 396.96 & 136.92 & 0.000 \\
\hline Linear & 3 & 1328.20 & 442.73 & 152.81 & 0.000 \\
\hline Temperature & 1 & 1277.71 & 1277.71 & 440.99 & 0.000 \\
\hline $\mathrm{H}_{2} \mathrm{SO}_{4}$ & 1 & 46.40 & 46.40 & 16.02 & 0.010 \\
\hline Time & 1 & 4.08 & 4.08 & 1.41 & 0.289 \\
\hline Square & 1 & 258.57 & 258.57 & 89.24 & 0.000 \\
\hline $\begin{array}{c}\text { Temperature } \times \\
\text { temperature }\end{array}$ & 1 & 258.57 & 258.57 & 89.24 & 0.000 \\
\hline Error & 5 & 14.49 & 2.90 & & \\
\hline Total & 9 & 1601.25 & & & \\
\hline \multicolumn{6}{|l|}{ Levulinic acid } \\
\hline Model & 4 & 206.11 & 51.53 & 58.11 & 0.000 \\
\hline Linear & 3 & 188.11 & 62.70 & 70.71 & 0.000 \\
\hline Temperature & 1 & 84.66 & 84.66 & 95.47 & 0.000 \\
\hline $\mathrm{H}_{2} \mathrm{SO}_{4}$ & 1 & 40.35 & 40.35 & 45.50 & 0.001 \\
\hline Time & 1 & 63.11 & 63.11 & 71.17 & 0.000 \\
\hline Square & 1 & 18.00 & 18.00 & 20.30 & 0.006 \\
\hline $\begin{array}{c}\text { Temperature } \times \\
\text { temperature }\end{array}$ & 1 & 18.00 & 18.00 & 20.30 & 0.006 \\
\hline Error & 5 & 4.34 & 0.89 & & \\
\hline Total & 9 & 210.55 & & & \\
\hline
\end{tabular}

selectivities, nearly all individual parameters had significant effect, except the effect of reaction temperature on acetic acid selectivity since individual term of reaction temperature had p-value of 0.088 . The response surface plots of hazelnut shell conversion and the selectivities of desired products with respect to reaction temperature and $\mathrm{H}_{2} \mathrm{SO}_{4}$ concentration were shown in Fig. 7. When reaction temperature increased to $200{ }^{\circ} \mathrm{C}$, conversion of hazelnut shell (Fig. 7a) and levulinic acid selectivity (Fig. 7b) was also increased. Additionally, formation of levulinic acid was approximately tripled with $50 \mathrm{mM} \mathrm{H}_{2} \mathrm{SO}_{4}$ concentration (9\%). Positive effect on the selectivity of acetic acid (Fig. 7c) was observed with $\mathrm{H}_{2} \mathrm{SO}_{4}$ treatment. Response surface plot of furfural (Fig. 7d)


pointed out that increase in reaction temperature until $200{ }^{\circ} \mathrm{C}$ resulted in the improvement of furfural formation; however, after $200^{\circ} \mathrm{C}$, furfural production decreased notably with a further temperature increment.

The optimized process parameters for both hazelnut shell conversion and the desired product selectivities were given in Fig. 8. When reaction was carried with the addition of $50 \mathrm{mM} \mathrm{H}_{2} \mathrm{SO}_{4}$ at a temperature of $224.36{ }^{\circ} \mathrm{C}$ for $120 \mathrm{~min}$, hazelnut shell conversion was recorded as 63.89\% and under same conditions levulinic acid selectivity was $13.17 \%$. Under the conditions of $224.75{ }^{\circ} \mathrm{C}$ reaction temperature for 15 min reaction time with $50 \mathrm{mM} \mathrm{H}_{2} \mathrm{SO}_{4}$, the conversion of hazelnut shell reached to maximum value of $65.31 \%$. Under same conditions, acetic acid selectivity was maximized as $12.87 \%$. Additionally, $61.53 \%$ of optimum hazelnut shell conversion and $11.60 \%$ of optimum furfural selectivity were acquired in the presence of $39.48 \mathrm{mM} \mathrm{H}_{2} \mathrm{SO}_{4}$ at a temperature of $201.52{ }^{\circ} \mathrm{C}$ for $15 \mathrm{~min}$.

\section{Conclusions}

Hydrothermal conversion of waste hazelnut shell to value-added chemicals such as levulinic acid was carried out in hot-compressed water under different reaction temperatures, reaction time, acid types and acid concentrations. Among various formed organic products, levulinic acid, acetic acid and furfural were determined as major compounds. The maximum hazelnut shell conversion (65.40\%) was obtained at $280{ }^{\circ} \mathrm{C}$ and $120 \mathrm{~min}$ reaction time in the presence of $50 \mathrm{mM} \mathrm{H}_{2} \mathrm{SO}_{4}$ concentration. As the reaction temperature increased, reaction pathway of levulinic acid was promoted, whereas under same conditions furfural selectivity greatly decreased. Addition of $\mathrm{H}_{2} \mathrm{SO}_{4}$ and $\mathrm{H}_{3} \mathrm{PO}_{4}$ to the reaction solution resulted in different product distribution in the liquor. The production of levulinic acid was greatly enhanced in the presence of $\mathrm{H}_{2} \mathrm{SO}_{4}$ in the reaction solution. In contrast, with the addition of $\mathrm{H}_{3} \mathrm{PO}_{4}$ the formation of furfural was accelerated. Therefore, hot compressed water as a reaction environment is a promising technology for adding value to waste hazelnut shell by producing bio-based chemicals such as levulinic acid, furfural and acetic acid. The levulinic acid
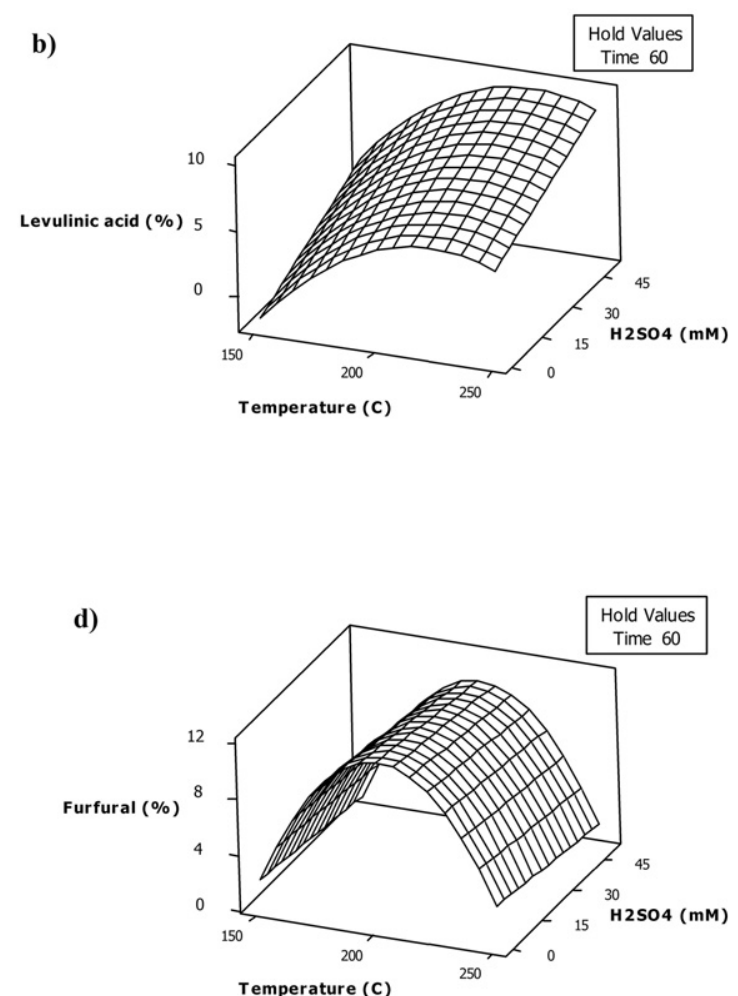

Fig. 7. The surface plots of a) hazelnut shell conversion, selectivities of b) levulinic acid; c) acetic acid and d) furfural with respect to reaction temperature and $\mathrm{H}_{2} \mathrm{SO}_{4}$ concentration. 


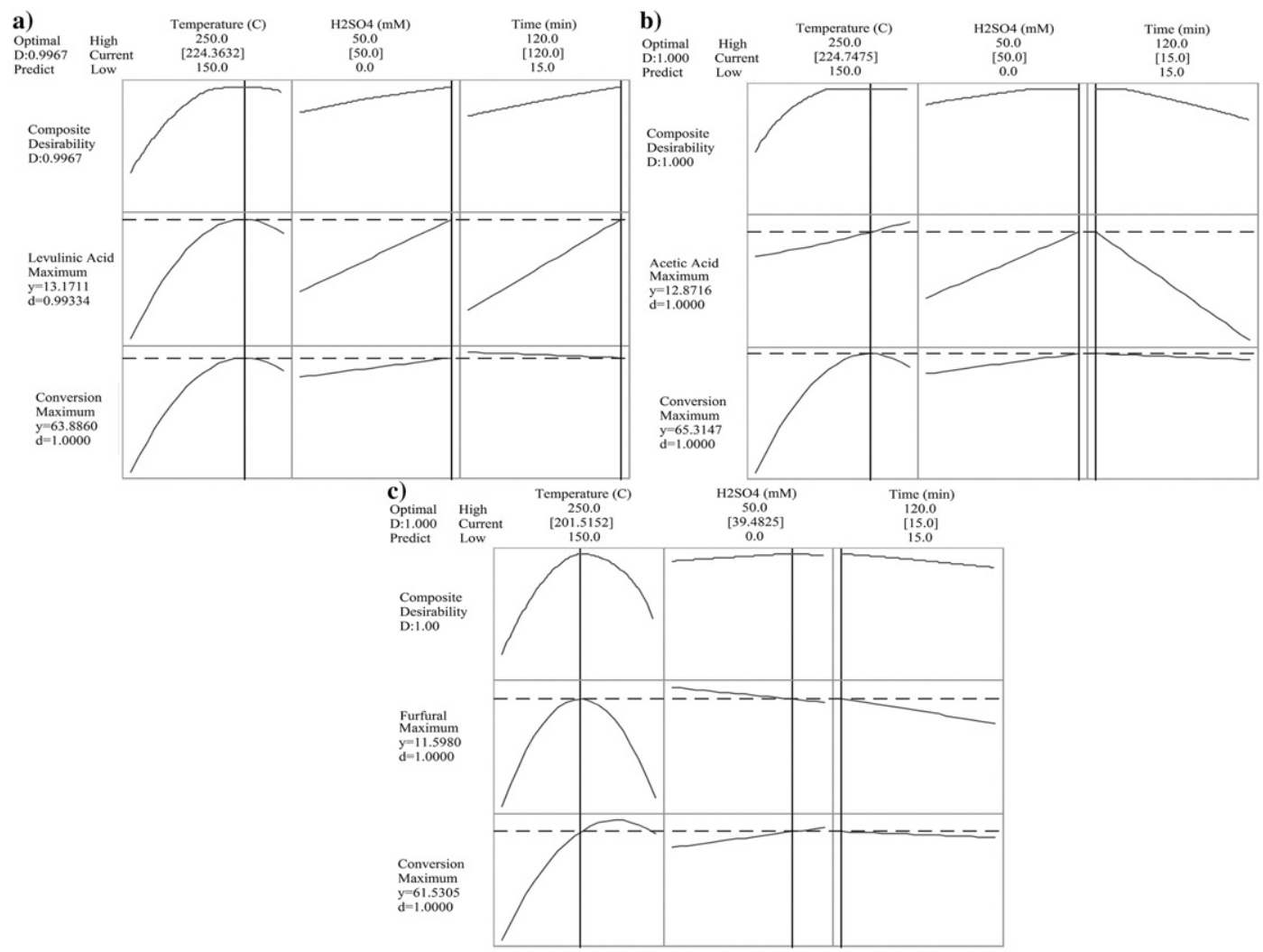

Fig. 8. Optimized operating conditions for the maximum hazelnut shell conversion and the maximum selectivities of a) levulinic acid; b) acetic acid and c) furfural.

selectivity from hazelnut shell can be utilized with acid hydrolysis pretreatment and using solid acid catalyst as further studies.

\section{Acknowledgments}

This research is financially supported by Marie Curie Career Integration Grants (FP7-PEOPLE-2012- CIG) with a project number of PCIG11GA-2012-321741. We would like to thank to Research Assistants Okan AKIN ( $\mathrm{PhD}$ candidate) and Emre DEMIRKAYA (PhD candidate) for their help during analyses. We would also like to thank to "Environmental Reference Research and Development Center" and "Biotechnology and Bioengineering Research and Application Center" at Izmir Institute of Technology for their support in product analysis.

\section{Appendix A. Supplementary data}

Supplementary data to this article can be found online at http://dx doi.org/10.1016/j.fuproc.2017.05.034.

\section{References}

[1] H. Mazaheri, K.T. Lee, A.R. Mohamed, Influence of temperature on liquid products yield of oil palm shell via subcritical water liquefaction in the presence of alkali catalyst, Fuel Process. Technol. 110 (2013) 197-205.

[2] M. Mohan, T. Banerjee, V.V. Goud, Hydrolysis of bamboo biomass by subcritical water treatment, Bioresour. Technol. 191 (2015) 244-252.

[3] R.C. Saxena, D.K. Adhikari, H.B. Goyal, Biomass-based energy fuel through biochemical routes: a review, Renew. Sust Energ Rev. 13 (2009) 167-178.

[4] D.W. Rackemann, W.O.S. Doherty, The conversion of lignocellulosics to levulinic acid, Biofuels Bioprod. Biorefin. 5 (2011) 198-214.

[5] M. Sasaki, T. Oshikawa, H. Watanabe, Wahyudiono, M. Goto, Reaction kinetics and mechanism for hydrothermal degradation and electrolysis of glucose for producing carboxylic acids, Res. Chem. Intermed. 37 (2011) 457-466.

[6] A. Kruse, N. Dahmen, Water - a magic solvent for biomass conversion, J. Supercrit. Fluids 96 (2015) 36-45.

[7] S. Kumar, R.B. Gupta, Biocrude production from switchgrass using subcritical water, Energy Fuel 23 (2009) 5151-5159.
[8] A. Kruse, E. Dinjus, Hot compressed water as reaction medium and reactant - properties and synthesis reactions, J. Supercrit. Fluids 39 (2007) 362-380.

[9] N. Akiya, P.E. Savage, Roles of water for chemical reactions in high-temperature water, Chem. Rev. 102 (2002) 2725-2750.

[10] Y.H. Chan, S. Yusup, A.T. Quitain, Y. Uemura, M. Sasaki, Bio-oil production from oil palm biomass via subcritical and supercritical hydrothermal liquefaction, J. Supercrit. Fluids 95 (2014) 407-412.

[11] A. Kruse, A. Gawlik, Biomass conversion in water at 330-410 degrees C and 30$50 \mathrm{MPa}$. Identification of key compounds for indicating different chemical reaction pathways, Ind. Eng. Chem. Res. 42 (2003) 267-279.

[12] L.M. Cheng, X.P. Ye, R.H. He, S. Liu, Investigation of rapid conversion of switchgrass in subcritical water, Fuel Process. Technol. 90 (2009) 301-311.

[13] Y. Takeuchi, F.M. Jin, K. Tohji, H. Enomoto, Acid catalytic hydrothermal conversion of carbohydrate biomass into useful substances, J. Mater. Sci. 43 (2008) 2472-2475.

[14] F.S. Asghari, H. Yoshida, Conversion of Japanese red pine wood (Pinus densiflora) into valuable chemicals under subcritical water conditions, Carbohydr. Res. 345 (2010) 124-131.

[15] M. Tymchyshyn, C.B. Xu, Liquefaction of bio-mass in hot-compressed water for the production of phenolic compounds, Bioresour. Technol. 101 (2010) 2483-2490.

[16] G.Y. Zhu, X. Zhu, Z.B. Xiao, R.J. Zhou, Y.L. Zhu, X.L. Wan, Kinetics of peanut shell pyrolysis and hydrolysis in subcritical water, J. Mater. Cycles Waste Manage. 16 (2014) 546-556.

[17] A. Liu, Y. Park, Z.L. Huang, B.W. Wang, R.O. Ankumah, P.K. Biswas, Product identification and distribution from hydrothermal conversion of walnut shells, Energy Fuel 20 (2006) 446-454.

[18] F. Shahidi, C. Alasalvar, C.M. Liyana-Pathirana, Antioxidant phytochemicals in hazelnut kernel (Corylus avellana L.) and hazelnut byproducts, J. Agric. Food Chem. 55 (2007) 1212-1220.

[19] M. Contini, S. Baccelloni, R. Massantini, G. Anelli, Extraction of natural antioxidants from hazelnut (Corylus avellana L.) shell and skin wastes by long maceration at room temperature, Food Chem. 110 (2008) 659-669.

[20] M.S. Guney, Utilization of hazelnut husk as biomass, Sustain. Energy Technol. Assess. 4 (2013) 72-77.

[21] B.S. Chiou, D. Valenzuela-Medina, C. Bilbao-Sainz, A.K. Klamczynski, R.J. AvenaBustillos, R.R. Milczarek, W.X. Du, G.M. Glenn, W.J. Orts, Torrefaction of pomaces and nut shells, Bioresour. Technol. 177 (2015) 58-65.

[22] H.K. Goering, P.J. Van Soest, Forage fiber analysis, Agricultural Handbook No. 379 1970, pp. 829-835.

[23] T.G. Madenoglu, E. Yildirir, M. Saglam, M. Yuksel, L. Ballice, Improvement in hydrogen production from hard-shell nut residues by catalytic hydrothermal gasification, J. Supercrit. Fluids 95 (2014) 339-347.

[24] O. Akin, A. Yuksel, Novel hybrid process for the conversion of microcrystalline cellulose to value-added chemicals: part 1: process optimization, Cellulose 23 (2016) 3475-3493. 
[25] A. Yuksel, Hydrothermal treatment of cellulose in hot-pressurized water for the production of levulinic acid, Uludağ Univ. J. Fac. Eng. 21 (2016) 415-434.

[26] D.J. Huang, B.X. Ou, R.L. Prior, The chemistry behind antioxidant capacity assays, J. Agric. Food Chem. 53 (2005) 1841-1856.

[27] F.P. Cardenas-Toro, S.C. Alcazar-Alay, T. Forster-Carneiro, M.A.A. Meireles, Obtaining oligo- and monosaccharides from agroindustrial and agricultural residues using hydrothermal treatments, Food Public Health 4 (2014) 123-139.

[28] M. Moller, P. Nilges, F. Harnisch, U. Schroder, Subcritical water as reaction environment: fundamentals of hydrothermal biomass transformation, ChemSusChem 4 (2011) 566-579.

[29] A. Yuksel, M. Sasaki, M. Goto, A new green technology: hydrothermal electrolysis for the treatment of biodiesel wastewater, Res. Chem. Intermed. 37 (2011) 131-143.

[30] H. Abdullah, H.W. Wu, Biochar as a fuel: 1. properties and grindability of biochars produced from the pyrolysis of mallee wood under slow-heating conditions, Energy Fuel 23 (2009) 4174-4181.

[31] J.G. Lynam, C.J. Coronella, W. Yan, M.T. Reza, V.R. Vasquez, Acetic acid and lithium chloride effects on hydrothermal carbonization of lignocellulosic biomass, Bioresour. Technol. 102 (2011) 6192-6199.

[32] S.M. Kang, X.L. Li, J. Fan, J. Chang, Solid fuel production by hydrothermal carbonization of black liquor, Bioresour. Technol. 110 (2012) 715-718.

[33] D.A. Laird, R.C. Brown, J.E. Amonette, J. Lehmann, Review of the pyrolysis platform for coproducing bio-oil and biochar, Biofuels Bioprod. Biorefin. 3 (2009) 547-562.

[34] O.S. Amuda, A.A. Giwa, I.A. Bello, Removal of heavy metal from industrial wastewater using modified activated coconut shell carbon, Biochem. Eng. J. 36 (2007) 174-181.

[35] T. Budinova, E. Ekinci, F. Yardim, A. Grimm, E. Bjornbom, V. Minkova, M. Goranova, Characterization and application of activated carbon produced by $\mathrm{H}_{3} \mathrm{PO}_{4}$ and water vapor activation, Fuel Process. Technol. 87 (2006) 899-905.

[36] X.D. Cao, L.N. Ma, B. Gao, W. Harris, Dairy-manure derived biochar effectively sorbs lead and atrazine, Environ. Sci. Technol. 43 (2009) 3285-3291.

[37] J. Lehmann, Bio-energy in the black, Front. Ecol. Environ. 5 (2007) 381-387.

[38] E. Marris, Putting the carbon back: black is the new green, Nature 442 (2006) 624-626.

[39] J.L. Gaunt, J. Lehmann, Energy balance and emissions associated with biochar sequestration and pyrolysis bioenergy production, Environ. Sci. Technol. 42 (2008) 4152-4158.

[40] S.P. Galinato, J.K. Yoder, D. Granatstein, The economic value of biochar in crop production and carbon sequestration, Energ Policy 39 (2011) 6344-6350.

[41] S. Kumar, V.A. Loganathan, R.B. Gupta, M.O. Barnett, An assessment of U(VI) removal from groundwater using biochar produced from hydrothermal carbonization, J. Environ. Manag. 92 (2011) 2504-2512.
[42] D. Savova, E. Apak, E. Ekinci, F. Yardim, N. Petrov, T. Budinova, M. Razvigorova, V. Minkova, Biomass conversion to carbon adsorbents and gas, Biomass Bioenergy 21 (2001) 133-142.

[43] M.M. Titirici, A. Thomas, M. Antonietti, Back in the black: hydrothermal carbonization of plant material as an efficient chemical process to treat the $\mathrm{CO}_{2}$ problem? New J. Chem. 31 (2007) 787-789.

[44] M. Sevilla, J.A. Macia-Agullo, A.B. Fuertes, Hydrothermal carbonization of biomass as a route for the sequestration of $\mathrm{CO}_{2}$ : chemical and structural properties of the carbonized products, Biomass Bioenergy 35 (2011) 3152-3159.

[45] J.W. Lee, B. Hawkins, D.M. Day, D.C. Reicosky, Sustainability: the capacity of smokeless biomass pyrolysis for energy production, global carbon capture and sequestration, Energy Environ. Sci. 3 (2010) 1695-1705.

[46] I. Pavlovic, Z. Knez, M. Skerget, Subcritical water - a perspective reaction media for biomass processing to chemicals: study on cellulose conversion as a model for biomass, Chem. Biochem. Eng. Q. 27 (2013) 73-82.

[47] Wahyudiono, M. Sasaki, M. Goto, Noncatalytic liquefaction of tar with low-temperature hydrothermal treatment, J. Mater. Cycles Waste Manage. 9 (2007) 173-181.

[48] O. Yakaboylu, G. Yapar, M. Recalde, J. Harinck, K.G. Smit, E. Martelli, W. de Jong, Supercritical water gasification of biomass: an integrated kinetic model for the prediction of product compounds, Ind. Eng. Chem. Res. 54 (2015) 8100-8112.

[49] J.L. Yu, P.E. Savage, Decomposition of formic acid under hydrothermal conditions, Ind. Eng. Chem. Res. 37 (1998) 2-10.

[50] F.L.P. Resende, Supercritical Water Gasification of Biomass, The University of Michigan, 2009 (Ph.D. Dissertation).

[51] Q. Fang, M.A. Hanna, Experimental studies for levulinic acid production from whole kernel grain sorghum, Bioresour. Technol. 81 (2002) 187-192.

[52] C. Promdej, Y. Matsumura, Temperature effect on hydrothermal decomposition of glucose in sub- and supercritical water, Ind. Eng. Chem. Res. 50 (2011) 8492-8497.

[53] M. Altun, S.E. Celik, K. Guclu, M. Ozyurek, E. Ercag, R. Apak, Total antioxidant capacity and phenolic contents of Turkish hazelnut (Corylus avellana L.) kernels and oils, J. Food Biochem. 37 (2013) 53-61.

[54] C. Stevigny, L. Rolle, N. Valentini, G. Zeppal, Optimization of extraction of phenolic content from hazelnut shell using response surface methodology, J. Sci. Food Agric. 87 (2007) 2817-2822.

[55] K. Watchararuji, M. Goto, M. Sasaki, A. Shotipruk, Value-added subcritical water hydrolysate from rice bran and soybean meal, Bioresour. Technol. 99 (2008) 6207-6213.

[56] A. Meillisa, H.C. Woo, B.S. Chun, Production of monosaccharides and bio-active compounds derived from marine polysaccharides using subcritical water hydrolysis, Food Chem. 171 (2015) 70-77. 